\title{
Aplikasi Pelayanan Surat Menyurat Desa Tanah Putih Berbasis Web
}

\author{
Suci Ramadhani ${ }^{\left.1^{*}\right)}$ \\ Program Studi Teknik Informatika, Politeknik Gorontalo \\ 60111, ${ }^{*}$ email : suci.mhs15@ti.poligon.ac.id
}

\author{
Fajar Hermawanto ${ }^{2)}$, Andi Mariani ${ }^{3)}$ \\ Program Studi Teknik Informatika, Politeknik Gorontalo \\ 60111, email : fajar@poligon.ac.id 2), \\ andi.marianidatu@poligon.ac.id ${ }^{3)}$
}

\begin{abstract}
Desa Tanah Putih merupakan salah satu Desa yang berada di Kecamatan Botupinnge. Pelayanan yang ada di Desa Tanah Putih meliputi pembuatan Surat Keterangan Usaha, Surat Keterangan Keramaian, Surat Keterangan Nikah, Surat Keterangan Domisili, Surat Keterangan Ekonomi Lemah, Surat Keterangan Pindah Sementara, Surat Keterangan Kelakuan Baik, Surat Keterangan Kelahiran, Surat Keterangan Pindah. Dalam melakukan pelayanan surat menyurat, masyarakat Desa Tanah Putih diwajibkan datang dan menunggu kepala Desa untuk menyelesaikan surat-surat tersebut. Pelayanan publik khususnya pengurusan surat menyurat yang ada di Desa tersebut masih terdapat beberapa kendala yang dihadapi masyarakat, khususnya ketika kepala Desa atau perangkat desa tidak berada di kantor Desa, sehingga masyarakat harus menunggu dan tidak mendapatkan pelayanan mengakibatkan proses pelayanan masyarakat berjalan lambat. Solusi yang diajukan untuk mengatasi permasalahan tersebut adalah membuat suatu aplikasi Pelayanan Surat Menyurat Desa Tanah Putih Berbasis Web. Sehingga untuk mempermudah masyarakat mengetahui informasi pengambilan permohonan surat menyurat dengan perkembangan teknologi berbasis web diharapkan dapat meningkatkan pelayanan yang memenuhi kebutuhan masyarakat dalam hal pelayanan Surat Menyurat di Kantor Desa Tanah Putih.
\end{abstract}

Kata Kunci : Pelayanan Surat Menyurat Desa, Web, Php, MySql.

\section{PENDAHULUAN}

Dalam UU. No. 23 tahun 2014 pemerintah Desa sebagai ujung tombak pemerintah yang merupakan akronim dari pemerintah pusat di mana berafiliasi langsung dengan masyarakat di harapkan dapat secara efektif dalam menjalankan tugas - tugas pemerintah sebagai pemerintah yang berada di desa guna terwujudnya pembangunan di segala bidang [5]. Dalam rangka membangun kualitas kinerja pemerintah yang efektif dan efisien diperlukan waktu untuk memikirkan bagaimana mencapai kesatuan kerjasama sehingga mampu meningkatkan kepercayaan masyarakat.

Desa Tanah Putih adalah salah satu lembaga tingkat Desa yang terletak di Kecamatan Botupingge Kabupaten Bonebolango. Adapun pelayanan kepada masyarakat di Desa Tanah Putih meliputi pembuatan Surat Keterangan Usaha, Surat Keterangan Keramaian, Surat Keterangan Nikah, Surat Keterangan Domisili, Surat Keterangan Ekonomi Lemah,
Surat Keterangan Pindah Sementara, Surat Keterangan Kelakuan Baik, Surat Keterangan Kelahiran, Surat Keterangan Pindah. Masyarakat diwajibkan datang dan menunggu kepala desa untuk menyelesaikan surat-surat tersebut. Hal ini membutuhkan waktu yang lebih lama, sehingga mengakibatkan lambatnya pengerjaan suatu layanan, ketidak jelasan informasi proses pembuatan surat telah selesai dan dapat menyita banyak waktu masyarakat untuk melakukan berbagai pelayanan surat apabila kepala desa atau petugas desa tidak berada di kantor desa.

Dengan perkembangan teknologi yang sangat pesat khususnya teknologi berbasis web dengan kelebihan mudah dikembangkan dari sisi bahasa pemogramannya dan pengaksesan informasi lebih mudah. Berdasarkan masalah yang terjadi dalam pelayanan masyarakat di Desa Tanah Putih maka penyelesaian masalah tersebut yaitu "Aplikasi Pelayanan Surat Menyurat Desa Tanah Putih Berbasis Web”. Dengan harapan aplikasi tersebut dapat mengatasi masalah yang dihadapi oleh masyarakat, yaitu masyarakat dapat membuat permohonan $\mathrm{s}$ urat secara online dan dapat mengetahui apakah surat tersebut telah selesai dibuat dan dapat diambil, sehingga menghemat waktu dan biaya transportasi dan membantu meringankan masyarakat di Desa Tanah Putih dalam mengurus berbagai keperluan, seperti untuk pelayanan di rumah sakit, beasiswa.

\section{METODE PENELITIAN}

Pada bagian ini menjelaskan mengenai gambaran umum pada Aplikasi Pembuatan Surat Menyurat Desa Tanah Putih Berbasis Web

2.1. Gambaran Umum Sistem

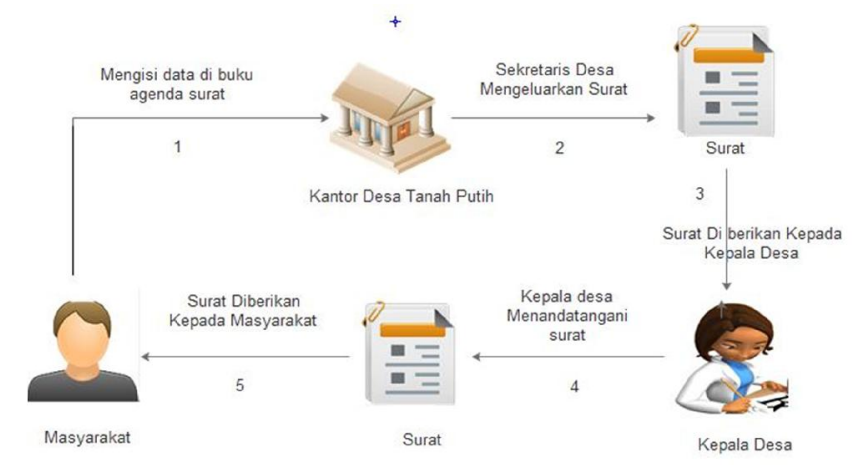

Gambar 1. Alur Sistem Yang berjalan 
Deskripsi Dari Gambaran Umum Sistem :

1. Masyarakat mendatangi ke kantor desa untuk melakukan pelayanan surat, kemudian mengisi data di buku agenda surat.

2. Sekretaris desa akan mengeluarkan surat berupa hasil print surat

3. Surat diberikan kepada Kepala Desa

4. Kepala desa menandatangani surat tersebut

5. Surat diberikan kepada masyarakat

Gambar 2 merupakan gambaran alur sitem yang di usulkan dari aplikasi pelayanan surat menyurat desa tanah putih berbasis web

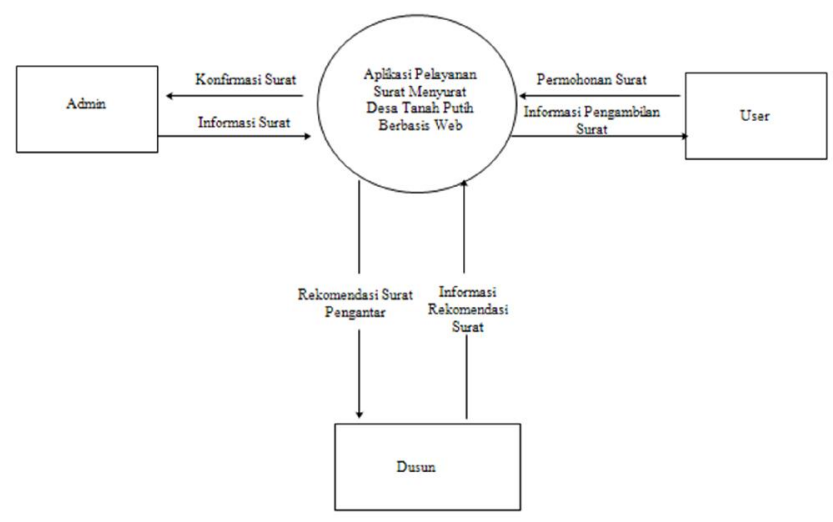

Gambar 2. Alur Sistem Yang di usulkan

Deskripsi dari alur sistem yang diusulkan

1. Admin disini adalah sebagai sekretaris desa pada aplikasi pelayanan surat menyurat. Sebelum masuk pada aplikasi admin diminta untuk login kemudian diarahkan ke form informasi surat, setelah pengonfirmasian surat akan dibuat dan dicetak.

2. User disini adalah sebagai masyarakat Desa tanah Putih, sebelum masuk pada aplikasi surat menyurat user diminta untuk login kemudian diarahkan ke form surat setelah itu ketua RT akan memberikan rekomendasi untuk pembuatan surat tersebut yang akan diketahui oleh admin.

3. Dusun disini bertugas untuk memberikan rekomendasi untuk pembuatan surat atau memberikan izin untuk pembuatan surat

\subsection{Usecase Diagram}

Diagram ini bersifat statis. Diagram ini memperlihatkan himpunan use case dan aktor-aktor (suatu jenis khusus dari kelas). Diagram ini terutama sangat penting untuk mengorganisasi dan memodelkan perilaku dari suatu sistem yang dibutuhkan serta diharapkan pengguna.

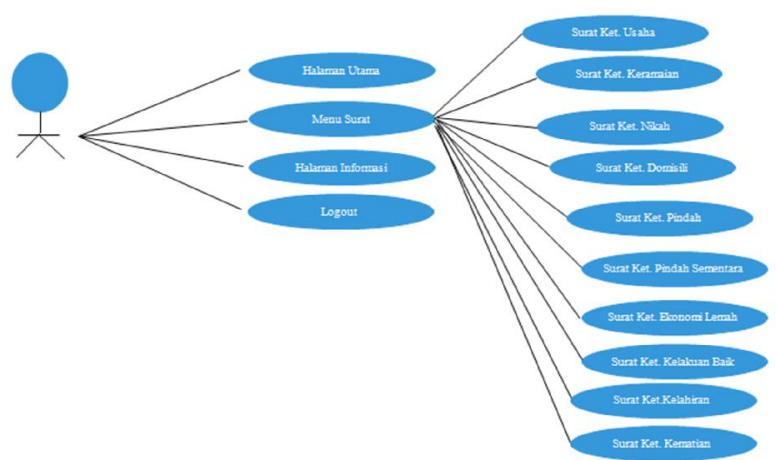

Gambar 3. Usecase Diagram User

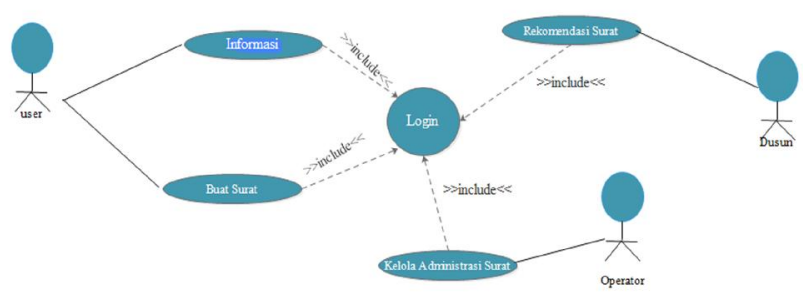

Gambar 4. Usecase interaksi antara sistem dan aktor

Sebelum mengakses aplikasi maka user diharuskan login sesuai dengan level pengguna dimana semua data terpusat pada satu sistem yaitu web server. Untuk mengetahui gambaran interaksi antara sistem dan aktor yang terlibat pada sistem yang dibuat

\subsection{Sequence Diagram}

Diagram ini bersifat dinamis. Diagram sequence merupakan diagram interaksi yang menekankan pada pengiriman pesan (message) dalam suatu waktu tertentu.

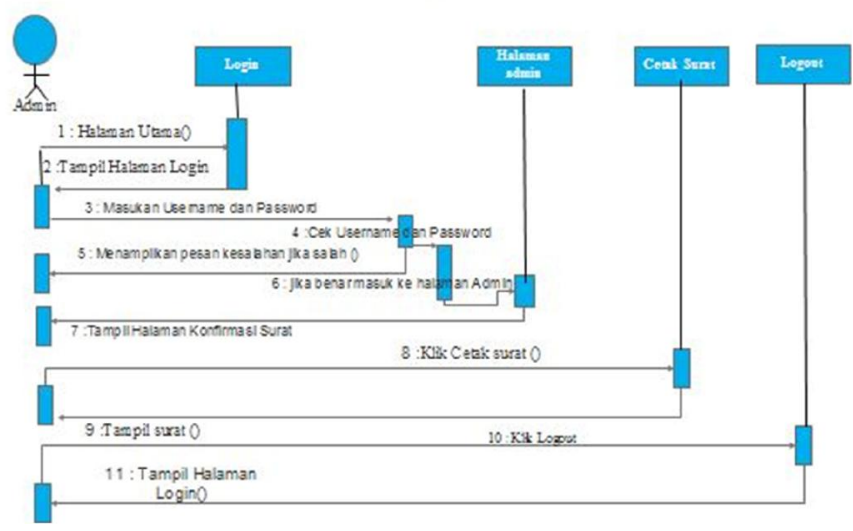

Gambar 5. Sequence Diagram Admin

Deskripsi dari sequence diagram admin : 
1. Admin mengakses halaman utama akan tampil halaman login, masukan username dan password mengecek jika salah akan menampilkan pesan kesalahan jika benar masuk halaman admin

2. Halaman admin digunakan untuk pengonfirmasian surat

3. Setelah itu cetak surat

4. Logout

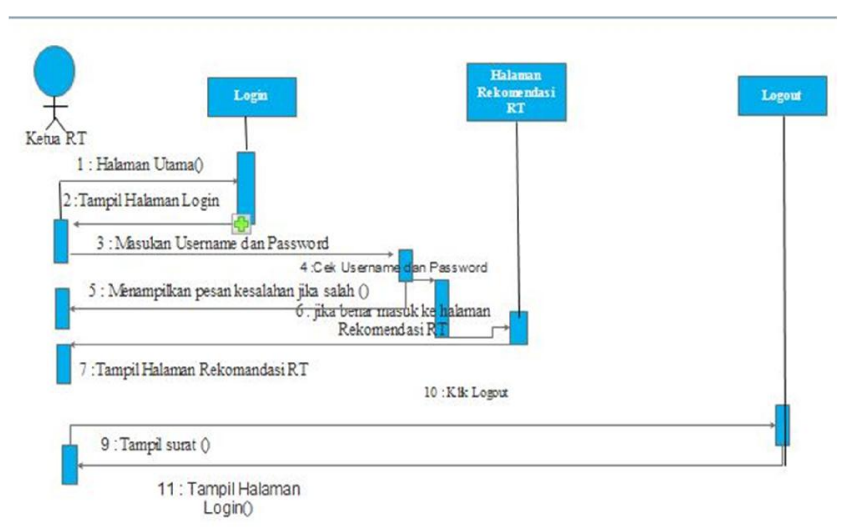

Gambar 6. Sequence Diagram Dusun

Deskripsi dari sequence diagram Rekomendasi RT :

1. Ketua RT mengakses halaman utama akan tampil halaman login, masukan username dan password mengecek username dan password jika salah akan menampilkan pesan kesalahan jika benar masuk halaman Rekomendasi Ketua RT

2. Halaman Rekomendasi Ketua RT digunakan untuk pengonfirmasian surat

3. Maka akan di tampilkan dihalaman admin bahwa user tersebut benar telah melakukan Rekomendasi Surat dari ketua RT

4. Logout

\section{HASIL DAN PEMBAHASAN}

3.1. Tampilan Halaman Depan

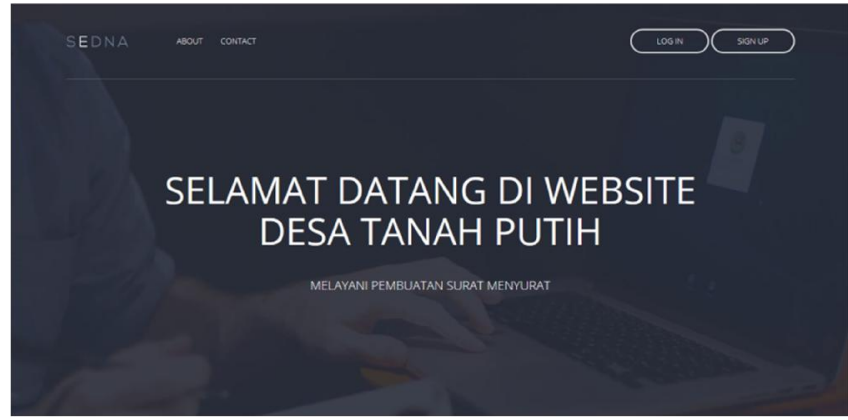

Gambar 7.Tampilan halaman depan

Gambar 7 Merupakan Tampilan halaman depan dari aplikasi surat menyurat desa berbasis website.

\subsection{Tampilan Halaman About}

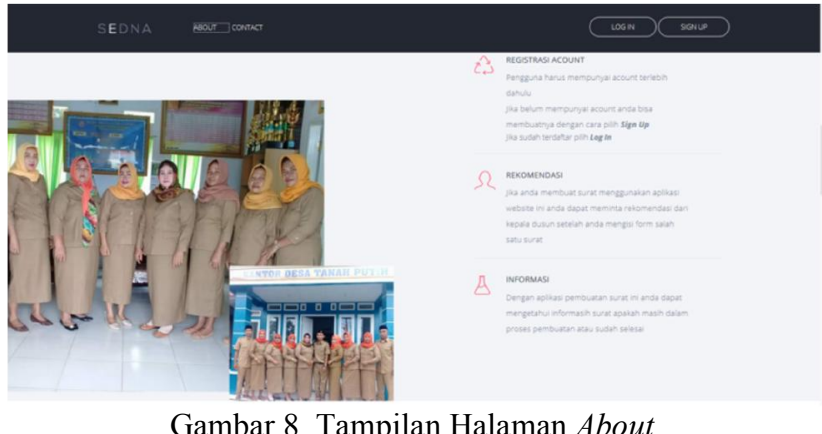

Gambar 8 merupakan tampilan about dari aplikasi surat menyurat desa berbasis website. Disini menjelaskan tata cara penggunaan aplikasi tersebut

3.3. Tampilan Halaman Contact

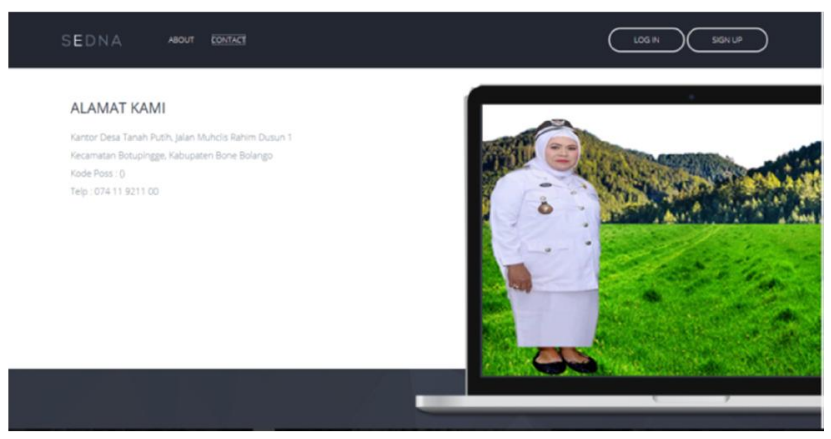

Gambar 9. Tampilan Contact

Gambar 9. merupakan tampilan Contact dari aplikasi surat menyurat desa berbasis website

\subsection{Tampilan Halaman Login}

\section{SEDNA wor contrat}

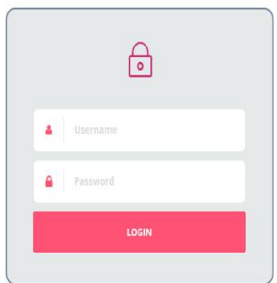

Gambar 10. Form Login

Gambar 10 merupakan tampilan form login dari aplikasi surat menyurat desa berbasis website, apabila sudah mempunyai akun bisa langsung menggunakan aplikasi tersebut 


\subsection{Tampilan Halaman Registrasi Akun}

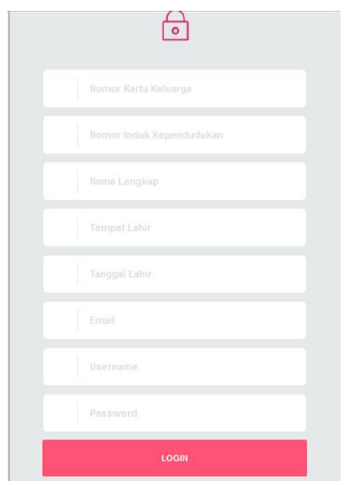

Gambar 11. Registrasi Akun

Gambar 11 merupakan tampilan Registarsi Akun dari aplikasi surat menyurat desa berbasis website.

\subsection{Tampilan Halaman Pemilihan Surat}

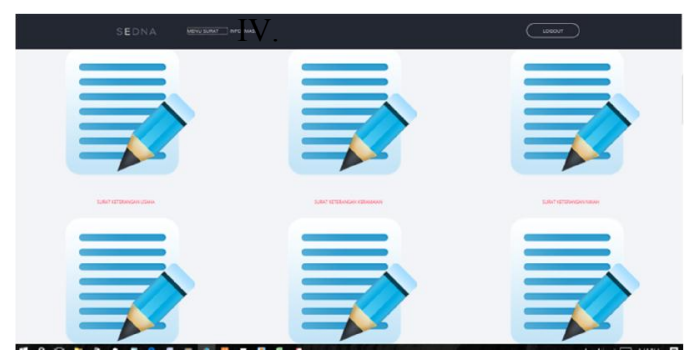

Gambar 12. Tampilan Menu Surat

Gambar 12 merupakan tampilan dari menu surat dari aplikasi surat menyurat desa berbasis website, apabila pengguna melakukan permohonan surat dapat memilih salah satu form surat.

3.7. Tampilan Surat Keterangan Usaha

Gambar 13 merupakan tampilan form surat ket usaha dari aplikasi surat menyurat desa berbasis website, disini pengguna dimintakan untuk mengisi identitas dengan benar.

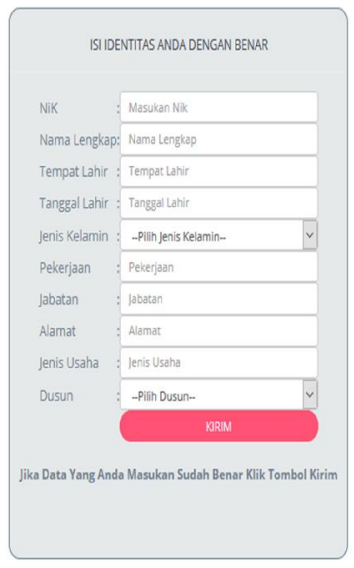

Gambar 13. Form Surat Ket.Usaha
3.8. Tampilan Surat Keterangan Keramaian

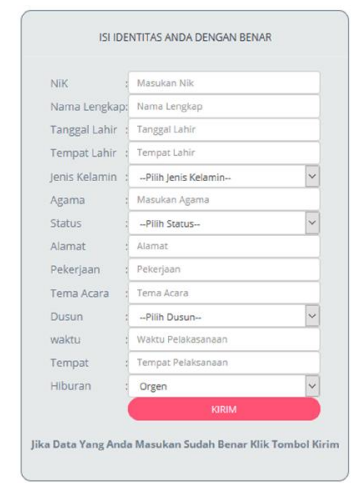

Gambar 14. Form Surat Ket. Keramaian

Gambar 14 merupakan tampilan form surat keramaian dari aplikasi surat menyurat desa berbasis website, apabila masyarakat melakukan permohonan surat Ket. Keramaian maka form tersebut akan tampil.

3.9. Tampilan Surat Keterangan Nikah

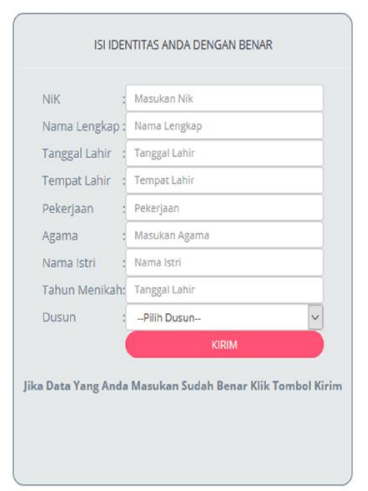

Gambar 15. Form Surat Ket. Nikah

Gambar 15 merupakan tampilan form surat keramaian dari aplikasi surat menyurat desa berbasis website, apabila masyarakat melakukan permohonan surat Ket. Nikah maka form tersebut akan tampil.

3.10. Tampilan Surat Keterangan Domisili

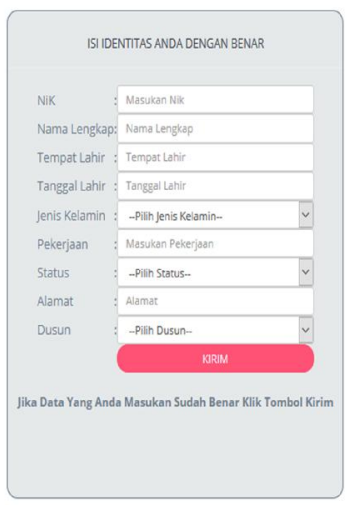

Gambar 16. Form Surat Ket. Domisili

ISSN : 2502-1613 
Gambar 16 merupakan tampilan form surat domisili dari aplikasi surat menyurat desa berbasis website, apabila masyarakat melakukan permohonan surat Ket. Domisili maka form tersebut akan tampil.

\subsection{Tampilan Surat Keterangan Pindah}

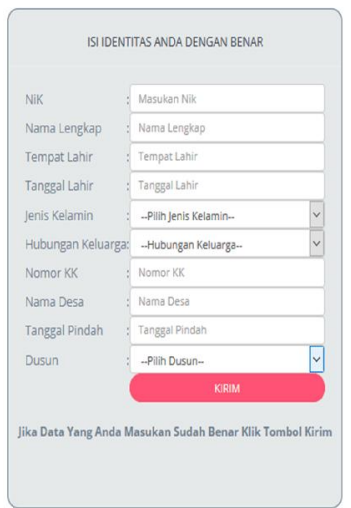

Gambar 17.Form Surat Ket. Pindah

Gambar 17 merupakan tampilan form surat pindah dari aplikasi surat menyurat desa berbasis website, apabila masyarakat melakukan permohonan surat Ket. Pindah maka form tersebut akan tampil.

3.12. Tampilan Surat Keterangan Pindah Sementara

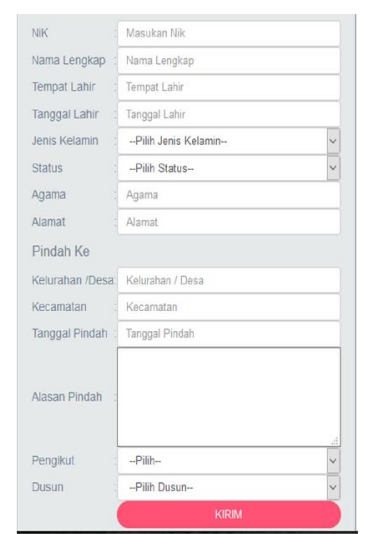

Gambar 18. Form Surat Ket. Pindah Sementara

Gambar 18 merupakan tampilan form surat pindah sementara dari aplikasi surat menyurat desa berbasis website, apabila masyarakat melakukan permohonan surat Ket. Pindah Sementara maka form tersebut akan tampil.

\subsection{Tampilan Surat Keterangan Ekonomi Lemah}

Gambar 19 merupakan tampilan form surat ekonomi lemah dari aplikasi surat menyurat desa berbasis website, apabila masyarakat melakukan permohonan surat Ket. Ekonomi Lemah maka form tersebut akan tampil.

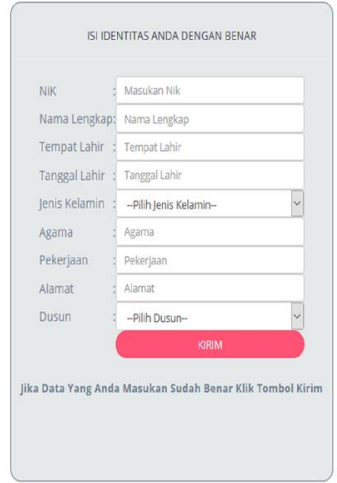

Gambar 19. Form Surat Ket Ekonomi Lemah

3.14. Tampilan Surat Keterangan Kelakuan Baik

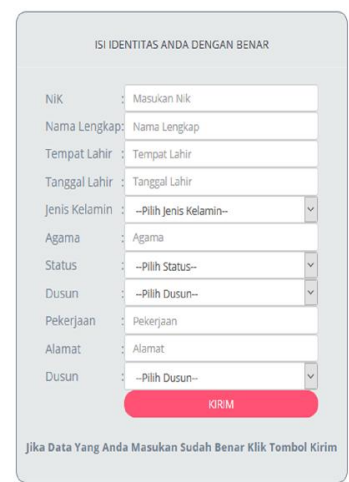

Gambar 20. Form Surat Ket Kelakuan Baik

Gambar 20 merupakan tampilan form surat keterangan kelakuan baik dari aplikasi surat menyurat desa berbasis website, apabila masyarakat melakukan permohonan surat Ket. Kelakuan Baik maka form tersebut akan tampil.

3.15. Tampilan Surat Keterangan Kelahiran

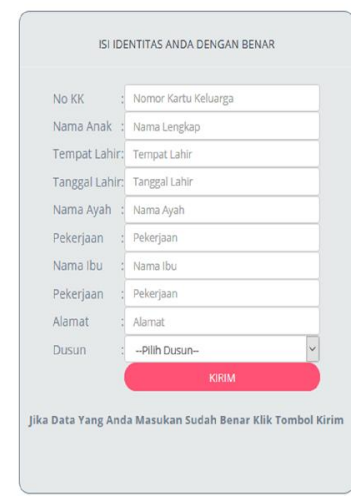

Gambar 21. Form Surat Ket Kelahiran

Gambar 21 merupakan tampilan form surat keterangan kelahiran dari aplikasi surat menyurat desa berbasis website, apabila masyarakat melakukan permohonan surat Ket. Kelahiran Baik maka form tersebut akan tampil. 


\subsection{Tampilan Surat Keterangan Kematian}

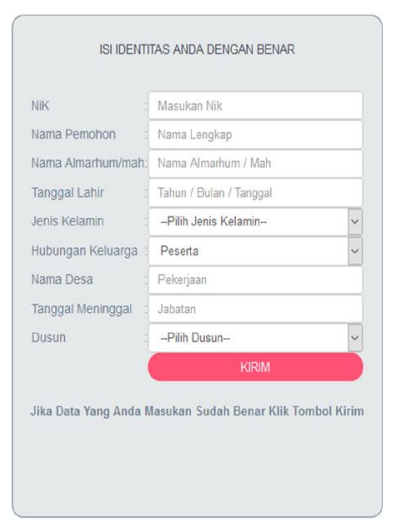

Gambar 22. Form Surat Ket Kematian

Gambar 23 merupakan tampilan form surat keterangan kematian dari aplikasi surat menyurat desa berbasis website, apabila masyarakat melakukan permohonan surat Ket. Kematian maka form tersebut akan tampil.

\subsection{Tampilan Halaman Informasi Surat}

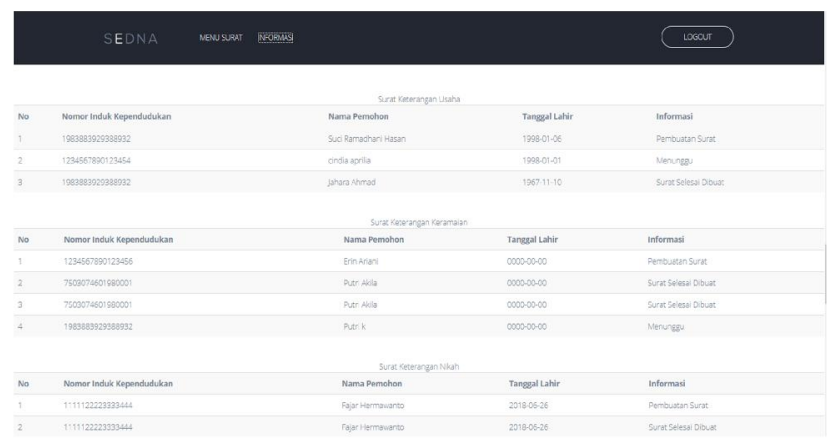

Gambar 24. Informasi Surat

Gambar 24 merupakan tampilan informasi surat dari aplikasi surat menyurat apabila pengguna telah mendapatkan rekomendasi dari ketua RT maka informasi yang diberikan akan terganti menjadi Proses Pembuatan atau Selesai.

\subsection{Tampilan Halaman Rekomendasi Kepala Dusun 1}

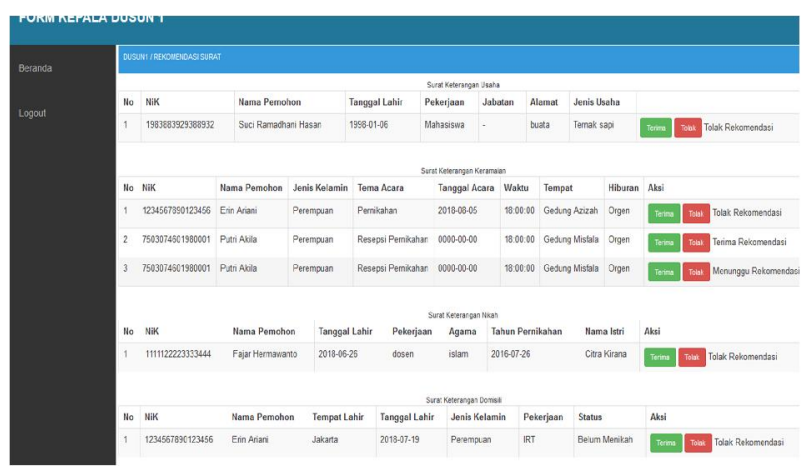

Gambar 25. Halaman Rekomendasi Kepala Dusun 1

Gambar 25 merupakan tampilan dari form rekomendasi kepala dusun 1 dari aplikasi surat menyurat Desa Tanah Putih berbasis web, di form ini hanya bisa diakses oleh kepala dusun 1 dan hanya bisa memberikan rekomendasi kepada pengguna berada di dusun 1 .

3.19. Tampilan Halaman Rekomendasi Kepala Dusun 2

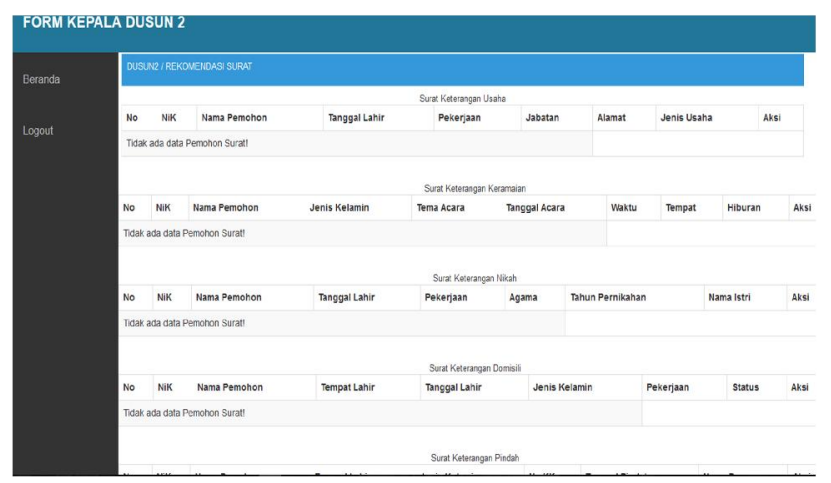

Gambar 26. Halaman Rekomendasi Kepala Dusun 2

Gambar 26 merupakan tampilan dari form rekomendasi kepala dusun, di form ini hanya bisa diakses oleh kepala dusun 2 dan hanya bisa memberikan rekomendasi kepada pengguna berada di dusun 2. Dari gambar tersebut menampilkan tidak ada data di dusun 2 .

\subsection{Tampilan Halaman Rekomendasi Kepala Dusun 3}

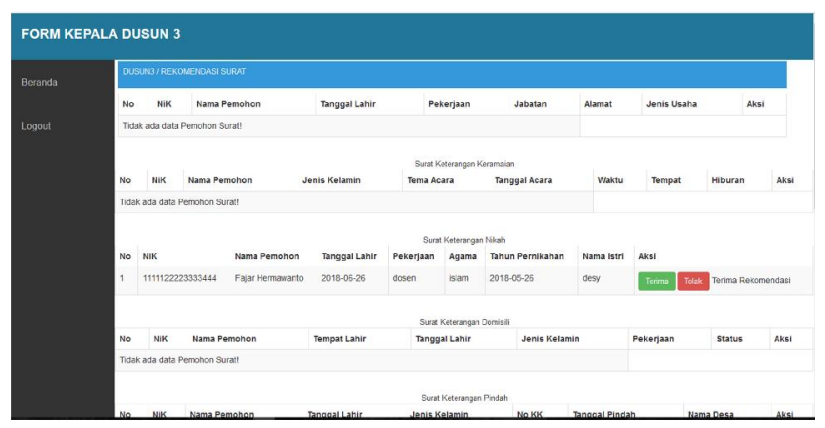

Gambar 27. Halaman Rekomendasi Kepala Dusun 3

Gambar 27 merupakan tampilan dari form rekomendasi kepala dusun, di form ini hanya bisa diakses oleh kepala dusun 3 dan hanya bisa memberikan rekomendasi kepada pengguna berada di dusun 3 .

\subsection{Tampilan Halaman Admin}

Gambar 28 merupakan tampilan admin disini admin bertugas untuk memberikan informasi sejauh mana pembuatan surat, button lihat berfungsih untuk melihat data keseluruhan dari pemohon surat dan apabila status telah disetujui oleh kepala dusun bisa langsung di Print. 


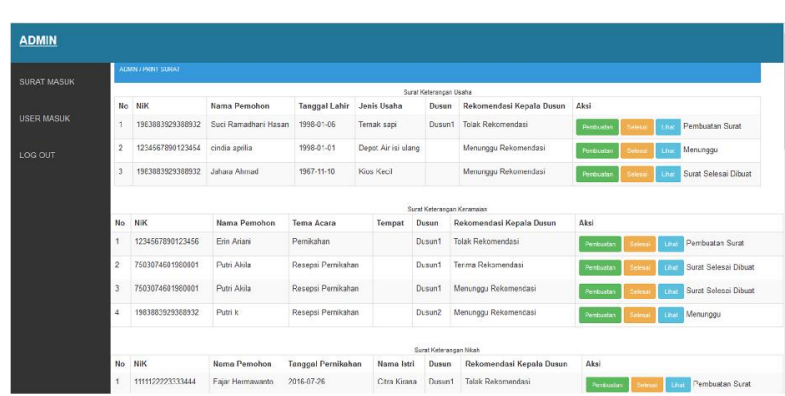

Gambar 28. Halaman Admin

3.22. Tampilan Halaman Cetak Surat

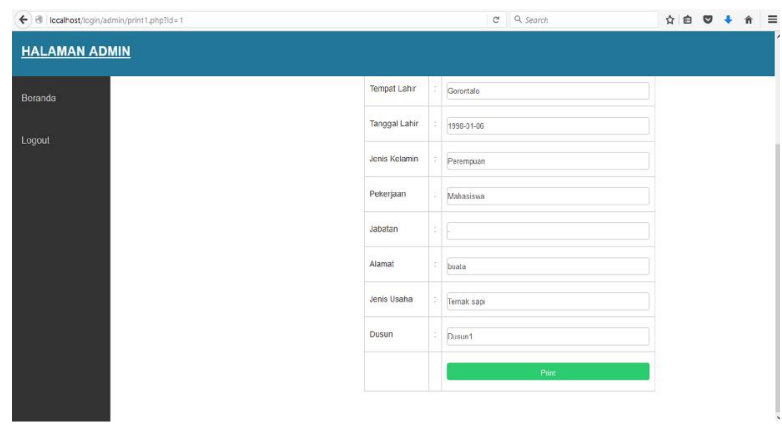

Gambar 29. Halaman Print Surat

Gambar 30 merupakan tampilan cetak surat dari aplikasi Surat Menyurat Desa Berbasis web, khususnya di Desa Tanah Putih Kecamatan Botupingge.

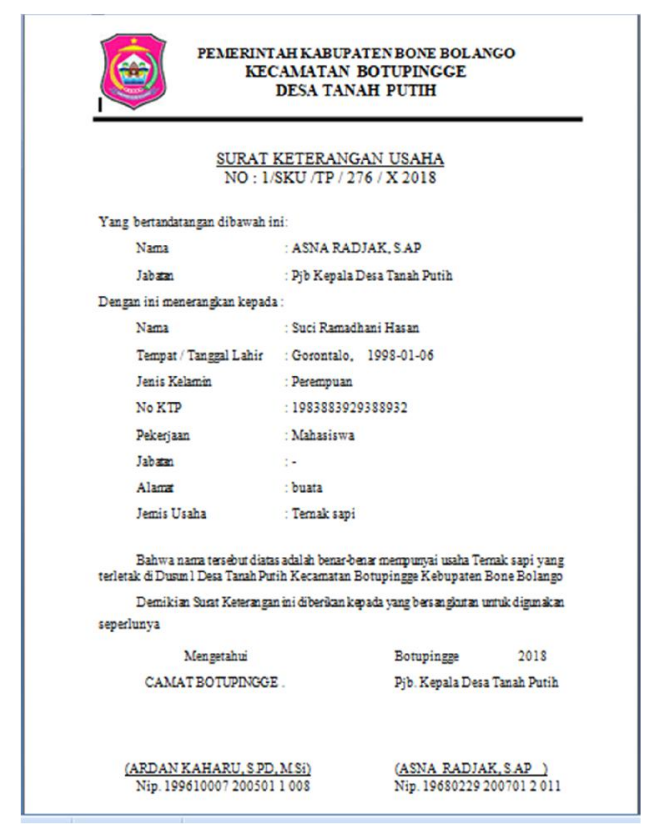

Gambar 30 Hasil Print

\section{KESIMPULAN}

Berdasarkan hasil pembuatan dan implementasi aplikasi yang telah dibuat, maka dapat ditarik kesimpulan bahwa Aplikasi Pelayanan Surat Menyurat Desa berbasis web ini bisa mengatasi kelemahan-kelemahan yang terjadi dalam pelayanan administrasi secara manual, aplikasi ini juga dapat membantu aparatur Desa dalam pembuatan surat khusus mencetak surat secara otomatis sudah terinput data dari pemohon surat.

\section{SARAN}

Dalam Aplikasi pelayanan surat menyurat desa berbasis web ini masih memilik kekurangan yaitu tanggal pembuatan surat masih diinputkan sesuai tanggal pembuatan surat maka perlu pengembangan lebih lanjut agar aplikasi ini dapat menjadi aplikasi yang handal.

\section{DAFTAR PUSTAKA}

[1] Febrian, Jack. 2004. Pengetahuan Komputer Dan Teknologi Informasi. Bandung : Informatika.

[2] Nugroho, B., 2007, PHP dan Mysql dengan Editor Dreamweaver $M x$, Yogyakarta : Andi.

[3] Rudyanto, Arief. 2011. Pemrograman Web Dinamis Menggunakan PHP Dan MySQL.Yogyakarta : Andi.

[4] Slamet dan Sutono Syahban. 1996. Surat-menyurat. Surakarta : CV Setiaji.

[5] Undang Undang Nomor 6 Tahun 2014 Tentang Desa.

[6] Virgi, Hirin. 2011. Cepat Mahir Pemrograman Web Dengan PHP dan MySQL. Jakarta: PT Prestasi Pustakaraya

[7] Westra, Pariata. 1973. Penyusunan Surat Dinas yang Efisien. Yogyakarta : Balai Pembinaan Administrasi UGM

[8] Widjaja, AW, 2002, Pemerintahan Desa dan Administrasi Desa, PT. Raja Grafindo Persada, Jakarta. 